\title{
Evaluation of Tomato (Solanum lycopersicum L.mill) Varieties for Yield and Fruit Quality in Ethiopia. A Review
}

\author{
Authors: Getachew Etana Gemechu (M.Sc) ${ }^{1}$ \\ Tewodros Mulalem Beyene (Ph.D) ${ }^{2}$ \\ Jimma Agricultural Research Center, EIAR.
}

\begin{abstract}
Tomato is one the most important vegetable crop in Ethiopia. Different variety evaluation experiments were conducted in regions and across regions of Ethiopia by research, higher learning institutions and non-governmental institutions. Among tomato varieties evaluated under open field and greenhouse condition at JUCAVM, variety Marglobe and Moneymaker showed the highest total fruit yield per plant in greenhouse. From ten improved tomato varieties with one local check evaluated at Agaro and Jimma for their yield, Varieties ARP tomato D2, showed superior and scored a marketable fruit yield of 22.18 ton ha ${ }^{-1}$ at Jimma and variety Fetan showed highest yield 10.67 ton $\mathrm{ha}^{-1}$ at Agaro. In Borena YPDARC, there were variations among the varieties evaluated in fruit yield ton $\mathrm{ha}^{-1}$. In Erer valley of Babile, Melka shola scored 30.86 ton ha ${ }^{-1}$ and Bishola 28.69 ton $\mathrm{ha}^{-1}$. Under irrigation deficit experiment both shoot and fruit weight loss was decreased with increase in stress level while the fruit dry matter weight increased. The total yield and marketable yields were decreasing as the deficit level was increased. Fruit soluble solid content increased with increase in water stress. Among the Hybrid varieties evaluated at Melkassa, Debreziet, Koka, Wonji and Ziway districts in Central Rift Valley of Ethiopia during off-season under irrigation, variety Venis was the highest yielding with preferable quality tomato. In the response to tested locations, Koka site show the highest total yield of 93.45 ton ha $^{-1}$ which is all most all double of Melkassa area. From the nine Evaluated tomato varieties at Humera agricultural research center (HARC), the highest marketable yield was obtained by Melkasalsa (56.07ton ha ${ }^{-1}$ ) and the least yield was recorded by Bishola (17.89 tonha ${ }^{-1}$ ).
\end{abstract}

Keywords: fruit quality, fruit yield, improved and hybrid variety.

DOI: $10.7176 / \mathrm{FSQM} / 89-03$

Publication date: August 31st 2019

\section{Introduction}

Tomato (Lycopersicon esculentum Mill.) is one of the most widely grown vegetable crops in the world. It is the $3^{\text {rd }}$ largest vegetable crop after potato and sweet potato and as a processing crop it ranks first among all vegetables (Agrisnet,2010).It originally came from tropical area from Mexico to Peru (Maerere et al., 2006; FAO, 2005). Its use as a food originated in Mexico, and spread throughout the world following the Spanish colonization of the Americas (Wikipedia, 2016).It is one of the most important edible and nutritious vegetable crops in the world. It is widely cultivated in tropical, subtropical and temperate climates and thus ranks third in terms of world vegetable production (FAO, 2006). The leading tomato producing countries are China is the biggest tomato producer in the world with annual production 34.1 million tons (FAOSTAT,2010), the United State of America, India, Egypt, Turkey, Iran, Mexico, Brazil and Indonesia (FAO, 2006).

In Ethiopia, there is no exact information as to when tomato was first introduced; however, the crop is cultivated in different major growing areas of the country. In 2015 cropping calendar, tomato production in Ethiopia was about 22,788 tons from harvested area of 3,677 ha. Ethiopia is the world's $84^{\text {th }}$ largest producer of tomato (CSA, 2012; CSA, 2015). In Ethiopia, tomato ranks fourth in total production (5.45\%) after Ethiopian cabbage, red pepper and green pepper are third in area coverage (4.49\%) next to red pepper and Ethiopian cabbage from vegetable crops cultivated. Its national mean yield is 6.2 ton/ha (CSA, 2015, Regassa et al., 2016). This is by far below the world average 34.84 ton/ha which is due to poor management practice in Ethiopia (Lemma, 2002).

It is used as canned vegetable having multiple uses and supplies essential nutrients in human diets (Choudhury, 1979). It is popularly used for both commercial and home use purposes. The fresh produce is sliced and used as salad.The processed products like tomato paste, tomato juice, and tomato catch-up. It is used in preparing soups, sauces, stews, salads and other dishes, and used in large quantities as compared to other vegetables. Its fruit is fairly nutritious and contains high amount of vitamins A, Vitamin C and whole peel-tomato are produced in the country for local market and export. It was recognized as quality product for both local and export markets and providing a route out of poverty for small scale producers who live in developing countries in general and in Ethiopia in particular (Tewodros and Asfaw, 2013).

In Ethiopia, several tomato varieties had been released nationally and recommended by the Melkassa Agricultural Research Center for commercial production and small scale farming systems in Ethiopia. The average yield of tomato in Ethiopia is low $\left(8\right.$ tonha $^{-1}$ ) compared with world average yields of 34 tonha $^{-1}$ (FAOSTAT, 2012). This may be related to limited access and use of improved commercial tomato varieties, adaptation and poor production management. As a result of these, different experiment were conducted in regions and across regions 
by researchers and higher learning institutions. The main objective this paper is to review different research experiment conducted on tomato variety evaluation for yield and fruit quality in different regions of Ethiopia.

\section{Tomato Production, Importance and Major Achievement in Variety Evaluation for Yield and Quality in Ethiopia in Ethiopia}

The climatic and soil conditions of Ethiopia allows the cultivation of a wide range of fruit and vegetable crops including tomato, which is largely grown in the eastern and central parts of the mid-to low-land areas of the country. The crop has been grown between 700 and 2200 meter above sea level having 700 to over $1400 \mathrm{~mm}$ annual rain fall in different seasons, under different weather conditions, at different levels of technology and yield (Birhanu and Ketema, 2010).

Large scale production of tomato takes place in the upper Awash valley under irrigated and rain-fed conditions whereas small scale production for fresh market is a common practice around Koka, Ziway, WondoGenet, Guder, Bako and many other areas (Lemma, 2002).In 2008, tomato production in Ethiopia reached about 41,815 tons from a total harvested area of $3542 \mathrm{ha}(\mathrm{FAO}, 2009)$. In Ethiopia, several tomato varieties were released nationally and recommended by the Melkassa Agricultural Research Center for both commercial production and small scale farming systems in Ethiopia. Varieties such as Melkashola and Marglobe are widely produced while Melkasalsa and Heinz 1350 have limited distribution and production. On the other hand, Fetan, Bishola, Eshete and Metadel are being tested (Lemma, 2002).

In Eastern part of Ethiopia, especially Harerghe farmers produce locally known tomato variety on their gardens which is very small in size and low fruit yield. Tomato production is rare due to shortage of rainfall and irrigation water unavailability. However, some farmers those settled around the rift valley of Babile produce local tomato on small units of land for consumption and rarely for income generation (CSA, 2016). The crop has high economic importance in the West Shewa of Ethiopia. A total of 7,255.93 hectares of land was under tomato in the country and yielding about $81,738.05$ tons of tomato production in Ethiopia (CSA, 2012). It is consumed in every household in different styles, but in certain areas, such as Walo, Hararge, Shawa, Jimma and Wallaga, it is also an important co-staple food (Ambecha et al., 2012). In Tigray Regional state, the western lowland of Tigray is one of the potential areas suitable for cultivation of tomato. The total cultivated area under tomato production in Kafta Humera woreda for 2013/2014 cropping season was 1,655 ha (Regassa et al., 2012). It can be eaten either fresh or processed into different products. It is used for healing wounds because of antibiotic properties found in ripe fruits. It is good source of Vitamins A, B and C (Baloch, 1994).

In Ethiopia, the demand of commercial hybrid vegetables seed has been rapidly increased. After adaptation and verification, more than 90 hybrid vegetable have been approved and registered for production in Ethiopia. Tomato takes the highest share of commercial vegetables. About 20 commercial hybrid tomato varieties have verified and under production in Ethiopia (MARDPR, 2016). Smallholders have grown tomato for long time for their livelihood needs since the start of its commercialization. However, the average yield of tomato in Ethiopia is low, 8 ton ha ${ }^{-1}$ compared with world average yields of 34 ton ha ${ }^{-1}$ (FAOSTAT, 2012). This may be related to limited access and use of improved commercial tomato varieties and poor production management.

\section{Tomato (Solanum lycopersicum L. mill) Yield and Fruit Quality Attributes as affected by Varieties and growth conditions in Jimma area}

Since 2011/2012 four improved tomato varieties: Eshete, Marglobe, Moneymaker and Bishola were tested under irrigation in greenhouse and open field condition at Jimma University College of Agriculture and Veterinary Medicine (JUCAVM). Result revealed that, Variety Moneymaker and Marglobe produced 7.28 and 6.84 fruits numbers per cluster respectively. This indicates that the differences among the varieties observed due to the highest number of flowers per cluster developed to fruits. Number of fruits per plant was higher in greenhouse than in open field. Among varieties, Moneymaker gave the highest number of fruits per plant (46.4) than any other tomato varieties. Fruit weight is one of the important traits that were directly linked with yield (Jindal et al., 2015). In greenhouse growing condition, variety Bishola produced fruits with average weight of $139.2 \mathrm{~g}$ per plant and followed by Eshete (130.0 g) and Marglobe (123.6 g) which may probably due to larger number of fruits per cluster (Yeshiwas et al., 2016). In line with this, Mohanty and Prusti (2006) reported that, genotype 'ET 35'scored large sized fruits $(92.67 \mathrm{~g})$. Also Shah et al. (2011) reported an average fruit weight $67.60 \mathrm{~g}$.

Harvested period of fruit varied among tomato varieties grown under greenhouse (Table 1). Variety Marglobe and Bishola had a total of 12 to 13 pickings in green house and a maximum of 5 to 6 rounds in open sun (Yeshiwas et al., 2016). 
Table 1.Number of fruits per cluster, number of fruit per plant, average fruit weight and number of harvest period of tomato varieties grown under greenhouse climate and open field

\begin{tabular}{|c|c|c|c|c|c|c|c|c|}
\hline \multirow[t]{2}{*}{ Varieties } & \multicolumn{2}{|c|}{$\begin{array}{l}\text { Number of fruits } \\
\text { per cluster }\end{array}$} & \multicolumn{2}{|c|}{$\begin{array}{l}\text { Number of fruit } \\
\text { per plant }\end{array}$} & \multicolumn{2}{|c|}{$\begin{array}{l}\text { Average fruit } \\
\text { weight }(\mathrm{g})\end{array}$} & \multicolumn{2}{|c|}{$\begin{array}{l}\text { Number of } \\
\text { fruit harvests }\end{array}$} \\
\hline & Green 1 & Oper & Green $\mathrm{h}$ & Open field & Green ho & Open field & Green 1 & $\begin{array}{l}\text { eOpen } \\
\text { field }\end{array}$ \\
\hline Bishola & $4.75 b$ & 5.37 & $26.11 \mathrm{c}$ & $21.83 b$ & $139.20 \mathrm{a}$ & 133.24 & $6.66 \mathrm{c}$ & 4.00 \\
\hline Eshete & $5.73 \mathrm{ab}$ & 4.37 & $26.32 c$ & $14.41 \mathrm{c}$ & $130.02 \mathrm{a}$ & 103.56 & $10.66 \mathrm{~b}$ & 3.66 \\
\hline Marglobe & $6.84 a$ & 5.45 & $35.47 b$ & $17.52 \mathrm{bc}$ & $123.60 \mathrm{a}$ & 140.01 & $12.66 \mathrm{a}$ & 5.00 \\
\hline Moneymaker & $7.28 \mathrm{a}$ & 4.76 & $46.36 \mathrm{a}$ & $31.91 \mathrm{a}$ & $94.72 b$ & 99.23 & $12.33 \mathrm{a}$ & 5.33 \\
\hline $\operatorname{LSD}(5 \%)$ & 1.91 & NS & 5.41 & 5.12 & 34.25 & NS & 1.29 & NS \\
\hline CV (\%) & 15.52 & 12.20 & 8.06 & 11.67 & 14.36 & 17.20 & 6.09 & 15.27 \\
\hline
\end{tabular}

Means followed by the same letter within the same column are not significantly different at 5\% level of significance. Source: (Yeshiwas et al., 2016).

Total fruit yield per plant in the greenhouse ranged from 1898 to 2144 g per plant, while the in open sun was from 1115 to $1505 \mathrm{~g}$ per plant. Among varieties tested, variety Marglobe and Moneymaker grown in greenhouse had the highest total fruit yield per plant. In open field the highest yield was obtained from Bishola and Moneymaker. Similarly, total fruit yield per hectare ranged from 86 to 102 and 53 to 71 ton ha ${ }^{-1}$, respectively for greenhouse and open field growing conditions (Yeshiwas et al., 2016). A yield by far less than this report was reported by indicating the potential yields of tomato ranged from 4.2 to 18.6 tons per hectare for the tomato varieties evaluated. Of these, the variety 'Soraya' presenting the highest mean yields of marketable fruit (Richardson, 2013).

A total soluble solid (TSS) is very important quality character and degree of sweetness is determined by TSS. Total soluble solids varied among varieties grown in greenhouse. Variety Eshete in green house scored the highest TSS (5.5 ${ }^{\circ}$ brix) while Moneymaker had the lowest in both growing conditions. As a result of this fact, tomato TSS is variety dependent. An agreement to this result, Jindal et al. (2015) stated that, the mean performance of three years of tomato TSS was recorded in the variety HS-18 (4.72 ${ }^{\circ}$ Brix) which was maximum TSS and followed by Dev and TAI-687 (3.99 Brix). Similar results were also reported by Zhu-wei Min et al. (2003) that indicate tomato cultivar 'Puhong 909' had maximum TSS content (4.5\%) under the multispan greenhouse. Singh (2011) also reported that, the maximum TSS was present in 'Naveen' (5.60) under naturally ventilated polyhouse. The value of total soluble solids content varied from $4.79 \%$ to $6.02 \%$ in different variety (Hossain et al., 2010). In line with this report, Dar et al. (2012); Gupta et al. (2011) were reported that, quality attributes like total soluble solids of the fruit ranged from 3.67 to $6.0^{\circ}$ Brix in different tomato varities.

Titratable acidity and $\mathrm{pH}$ are the most commonly used acidity indicators of tomato and influenced by both growing conditions and differences in tomato varieties (Table 2). The highest TA and $\mathrm{pH}$ were observed in greenhouse than in open field. Among the varieties, Marglobe had the highest value for both variables (Yeshiwas et al., 2016).Tomatoes dry matter production was also founded to be affected by both varieties and growing conditions (Table 2). In greenhouse, variety Marglobe accumulated the highest dry matter. In open sun, maximum dry matter was accumulated in the variety Moneymaker (Yeshiwas et al., 2016). An agreement to this, Davis and Hobson (1981) also found the variation in dry matter content among the different variety of tomato. Dry matter content of tomato grown in greenhouse ranged from 13 to $22 \%$ while 12 to $18 \%$ in open field condition (Yeshiwas et al., 2016). In line with this report, Hossain et al. (2010) reported that, the range of dry matter $10.60 \%$ to $17.54 \%$ for different varities of tomato.

Table 2 .Total soluble solid ( ${ }^{\circ}$ Brix), Titratable acidity, $\mathrm{pH}$ and dry matter content of tomato varieties grown under greenhouse and open field climate condition.

\begin{tabular}{|c|c|c|c|c|c|c|c|c|}
\hline \multirow[t]{2}{*}{ Varieties } & \multicolumn{2}{|c|}{ Total soluble solids ( ${ }^{\circ}$ Brix) } & \multicolumn{2}{|c|}{$\begin{array}{c}\text { Titratable acidity (\% } \\
\text { citric acid) }\end{array}$} & \multicolumn{2}{|r|}{$\mathrm{pH}$} & \multicolumn{2}{|c|}{ Dry matter content } \\
\hline & $\begin{array}{l}\text { Green } \\
\text { house }\end{array}$ & Open field & $\begin{array}{l}\text { Green } \\
\text { house }\end{array}$ & Open field & $\begin{array}{l}\text { Green } \\
\text { house }\end{array}$ & Open field & Green house & $\begin{array}{l}\text { Open } \\
\text { field }\end{array}$ \\
\hline Bishola & $4.16 \mathrm{c}$ & 5.33 & $0.24 \mathrm{a}$ & $0.21 \mathrm{ab}$ & $4.31 \mathrm{~b}$ & $4.38 \mathrm{a}$ & $12.59 \mathrm{c}$ & $17.37 \mathrm{a}$ \\
\hline Eshete & $5.50 \mathrm{a}$ & 5.33 & $0.15 b$ & $0.25 \mathrm{a}$ & $4.07 \mathrm{~b}$ & $3.87 \mathrm{~b}$ & $15.94 b c$ & $12.00 \mathrm{~b}$ \\
\hline Marglobe & $4.83 b$ & 5.00 & $0.28 \mathrm{a}$ & $0.17 \mathrm{bc}$ & $4.57 \mathrm{a}$ & $4.29 \mathrm{a}$ & $21.47 \mathrm{a}$ & $17.56 \mathrm{a}$ \\
\hline Moneymaker & $4.16 \mathrm{c}$ & 4.50 & $0.12 b$ & $0.13 \mathrm{c}$ & $4.30 \mathrm{~b}$ & $4.34 \mathrm{a}$ & $17.23 b$ & $17.66 \mathrm{a}$ \\
\hline $\operatorname{LSD}(5 \%)$ & 0.471 & NS & 0.046 & 0.053 & 0.243 & 0.268 & 4.035 & $3.272 \mathrm{c}$ \\
\hline $\mathrm{CV}(\%)$ & 5.05 & 7.20 & 11.42 & 13.87 & 2.59 & 3.18 & 12.01 & $10.14 \mathrm{~b}$ \\
\hline
\end{tabular}

Means followed by the same letter within the same column are not significantly different at $5 \%$ level of significance

Source: (Yeshiwas et al., 2016). 
Evaluation and adaptation of tomato varieties in Jimma, South West Ethiopia.

Since 2014/15 ten improved tomato varieties with one local check were evaluated at Agaro and Jimma for their yield and yield component by Jimma Agricultural research center. Varieties ARP tomato D2, Cochoro and Fetan gave the highest fruit cluster 8,7 and 7 per plant respectively. Similarly, variety ARP tomato D2 showed superior in the rest parameters and scored a marketable fruit yield of 22.18 ton $\mathrm{ha}^{-1}$ followed by Cochoro which scored highest marketable fruit yield of 16.89 ton $\mathrm{ha}^{-1}$ (JARC, 2014/15). This indicate that, variety vary from each other. An agreement to this, the variety Martha Washington scored greater marketable yield (44,092 lbs /acre) (Shubin et al., 2013). Also, Pruden's Purple variety had higher marketable yield (28,024 lbs/acre) than all other heirloom varieties with the exception of Cherokee Purple (Shubin et al., 2013). At Agaro; Melka Salsa showed highest in marketable fruit cluster per plant and marketable fruit number per plant (JARC, 2014/15). In similar manner, variety Martha Washington scored greater marketable fruit number (110,183 fruit/acre) over season tested compared to any of the heirloom varieties (Shubin et al., 2013)

In yield, Fetan variety showed highest difference from the rest treatment followed by Chali and Melka Salsa 10.67 ton ha- $\mathrm{ha}^{-1} 9.64$ ton $\mathrm{ha}^{-1}$ and 9.48 ton $\mathrm{ha}^{-1}$ respectively. The varieties were well adapted at Jimma than at Agaro with good performance in yield and yield related variables (JARC, 2014/15). Contrary to this, as varietal difference was obvious, the variety UC82B produce more total fruit yield $\mathrm{ha}^{-1}$ than Roma VF where it had $10.6 \%$ higher on the average (Isah et al., 2014). In same way, Olaniyi et al. (2010) reported that, the highest fruit yield values were recorded from UC82B wand closely followed by Ibadan and Ogbomoso Local with better growth, marketable and good quality fruit yield performance under hazardous climatic condition Oyo sate of Nigeria.

Since 2015/16 the same varieties were re-evaluated at Jimma for their Yield and yield component. The result showed that all the parameters were different from each other in varieties. Accordingly, the variety Melka Salsa was the highest in fruit number per plant (54) and flowed by local and Cochoro varieties (JARC, 2015). In line with this result, variety Martha Washington scored higher fruit number (110,183 fruit/ acre) over season tested compared to any of the heirloom tomato varieties (Shubin et al., 2013)

In fruit cluster per plant, the local one showed the highest and followed by Melkasalsa. In yield ton per hectare Melka salsa and local showed highest which is 35.66 and 35.76 ton per hectare respectively and followed by Cochoro with 25.13 ton per hectare. In general the highest yield was obtained from Melka salsa and the lowest yield was obtained from Bishola verities which had direct relationship with fruit number and cluster per plant (JARC, 2015). Close to but below this value of tomato yield, Adelana (1978) reported that, about 20 tons per hectare of tomato yield in temperate region.

Tomato variety evaluation under irrigation of tap water in Borena area, Southern Ethiopia.

Four improved varieties of tomato: Fetan, Melkashola, Miya and Cochoro from Melkassa Agricultural Research Center and one variety called CAL-J introduced from Kenya, were evaluated for their adaptation at Yabello pastorial development agricultural research center (YPDARC). The result showed that, there was a variation among the varieties for all most all parameters (Regassa et al., 2016). Variety Miya gave higher marketable fruit yield and higher average of single marketable fruit weight than other varieties (Regassa et al., 2016). In line this result, weights per plant ranged from $0.6 \mathrm{~kg}$ per plant for 'Yellow Jubilee' to $2.1 \mathrm{~kg}$ per plant for 'Soraya' (Richardson, 2013). The variety "Soraya"” also had the highest marketable fruit weights per plant and the largest number of marketable fruit per plant (Richardson, 2013). The least mean marketable fruit yield was obtained from the variety Fetan (Regassa et al., 2016). The mean marketable fruit yield obtained (11.61 to 22.95 ton ha ${ }^{-1}$ ) was an agreement to the result reported by Lemma (2002) with a mean marketable fruit yield between 7.21 to 48.80 ton $\mathrm{ha}^{-1}$. Marketable fruit yield was significantly and positively correlated with fruit number per plant and single fruit weight which indicates that, varieties with higher fruit number per plant and single fruit weight gives high marketable fruit yield (Regassa et al., 2016).

\section{Performance Evaluation of Tomato Varieties for Yield and yield component under Supplemental Irrigation} at Erer Valley, Babile District, Ethiopia.

Ten tomato varieties, five of which are determinate (Chali, Bishola, Melka Shola, Melka Salsa, Fetane) while another four are indeterminate (Miya, Eshete, Metadel and R/VF) with one farmers' genotypes (Babile local) were evaluated in Erer valley of Babile Woredas in Harer city, Eastern part of Ethiopia under irrigation for two consecutive years during offseason (Benti et al., 2017). Result indicated that, mean value of plant height ranges between $39.34 \mathrm{~cm}$ and $96.67 \mathrm{~cm}$. The tallest plant was Eshete followed by Babile local, R/VF and Melkashola over the two years while the shortest were Chali, Miya, Melkasalsa and Fetane (Benti et al., 2017). This result was agree with the findings of Meseret et al. (2012) who reported that, the plant height of tomato varieties range between $40.20 \mathrm{~cm}$ and $107.00 \mathrm{~cm}$.

Total fruit yield per hectare and average fruit weight were different among the varieties (Table 3). Bishola and Metadel were the biggest fruit size and maximum fruit weight while the remaining varieties were smallest in fruit weight. The maximum fruit yield per hectare were obtained from Melkashola, Bishola while the minimum 
were from Chali, Fetan and 'Babile local (Table 3) (Benti et al., 2017). In line to these varieties scored minimum result, tomato variety DT97/215A gave the least values (Olaniyi et al., 2010). The varietal differences in growth and yield might be attributed to the differences in ecological distribution of the tomato varieties. Besides the differences of varietal, due to the genetic makeup; the low marketable yield obtained for some tomato varieties used might be due to non-development of flowers into fruits as about $50 \%$ of the flowers developed into fruits. In line to this, Adelana(1975) reported that, only $50 \%$ of the flowers developed into fruits. Ecological conditions can also affect the fruit yield of tomato. An agreement to this, poor fruit set in tomato may be as a result of high temperatures that are not conducive for good fruit set (Simon and Sobulo, 1974; Olaniyi, 2007)

\begin{tabular}{ccccccc}
\multicolumn{6}{c}{ Table 3. Mean performance of yield and some agronomic parameter of two years (2012-2014) } \\
\hline Treatments & $\begin{array}{c}\text { Plant height } \\
(\mathrm{cm})\end{array}$ & $\begin{array}{c}\text { days to } \\
50 \% \text { flow }\end{array}$ & Clusters/plant & Fruits/Cluster & $\begin{array}{c}\text { Fruit } \\
\text { weight }(\mathrm{g})\end{array}$ & $\begin{array}{c}\text { Fruit yield } \\
(\mathrm{kg} / \mathrm{ha})\end{array}$ \\
\hline Miya & $44.63 \mathrm{~cd}$ & $36.50 \mathrm{c}$ & $14.87 \mathrm{de}$ & $3.167 \mathrm{ab}$ & $41.50 \mathrm{~b}$ & $24762 \mathrm{abc}$ \\
Chali & $39.43 \mathrm{~d}$ & $39.17 \mathrm{abc}$ & $14.27 \mathrm{def}$ & $2.667 \mathrm{~b}$ & $42.67 \mathrm{~b}$ & $19494 \mathrm{c}$ \\
Bishola & $56.23 \mathrm{bcd}$ & $37.00 \mathrm{c}$ & $15.43 \mathrm{~d}$ & $2.667 \mathrm{~b}$ & $87.83 \mathrm{a}$ & $28690 \mathrm{a}$ \\
Eshete & $96.67 \mathrm{a}$ & $39.67 \mathrm{abc}$ & $11.83 \mathrm{ef}$ & $3.000 \mathrm{ab}$ & $39.33 \mathrm{~b}$ & $26964 \mathrm{ab}$ \\
M/shola & $60.87 \mathrm{bc}$ & $42.00 \mathrm{a}$ & $24.63 \mathrm{a}$ & $3.333 \mathrm{ab}$ & $47.67 \mathrm{~b}$ & $30863 \mathrm{a}$ \\
M/salsa & $46.23 \mathrm{~cd}$ & $38.50 \mathrm{bc}$ & $17.50 \mathrm{~cd}$ & $3.167 \mathrm{ab}$ & $32.67 \mathrm{~b}$ & $24940 \mathrm{abc}$ \\
Fetan & $46.40 \mathrm{~cd}$ & $39.67 \mathrm{abc}$ & $11.07 \mathrm{f}$ & $1.883 \mathrm{c}$ & $46.83 \mathrm{~b}$ & $19137 \mathrm{c}$ \\
R/ VF & $64.00 \mathrm{bc}$ & $37.67 \mathrm{c}$ & $20.37 \mathrm{bc}$ & $3.333 \mathrm{ab}$ & $40.50 \mathrm{~b}$ & $20402 \mathrm{bc}$ \\
Metadel & $53.03 \mathrm{bcd}$ & $36.17 \mathrm{c}$ & $15.63 \mathrm{~d}$ & $3.667 \mathrm{a}$ & $80.50 \mathrm{a}$ & $25268 \mathrm{abc}$ \\
Local & $71.07 \mathrm{~b}$ & $40.67 \mathrm{ab}$ & $23.33 \mathrm{ab}$ & $3.500 \mathrm{ab}$ & $34.00 \mathrm{~b}$ & $18557 \mathrm{c}$ \\
\hline LSD & 24.6 & 4.359 & 4.304 & 0.9454 & 19.04 & 8478.1 \\
\hline CV\% & 25.7 & 6.8 & 15.4 & 20.1 & 23.3 & 21.5 \\
\hline
\end{tabular}

Source: (Benti et al., 2017)

Evaluation of drip irrigated Tomato genotypes for Fruit yield and quality under deficit Irrigation at Melkassa, Central rift valley of Ethiopia

Four level of irrigation deficit level $(0 \%, 25 \%, 50 \%$ and $75 \%)$ assigned as main plot and two tomato varieties were Melkashola (semi determinate) and Melkassa Marglob (indeterminate) to subplot and evaluated in split pilot design. Result indicated that, total plant fresh biomass (shoot and fruit weight) at maturity of both tomato cultivars was significantly affected by irrigation water applied. Both shoot and fruit weight loss was decreased with increase in stress level. While shoot dry weight consistently decreased with increase in stress level, the fruit dry matter weight increased. The fruit dry matter increased by $29.1 \%, 37.9 \%$, and $39.3 \%$ for Melka Shola cultivar and $17.2 \%, 19.3 \%$, and $23.9 \%$ for Melkassa Marglobe, at 25\%, 50\%, 75\% deficit levels relative to the non-stressed treatment $(0 \%$ deficit level).There was a significant difference between the cultivars regarding shoot and fruit dry weights. However, there was a non-significant difference for the interaction effect of cultivar and irrigation (Birhanu and Tilahun, 2010).

The harvest indices HI (which is fruit dry matter weight per plant dry weight) were significantly affected by irrigation deficit levels. The harvest index was higher for more stressed tomatoes of both cultivars, an indication of high dry matter accumulation as the crop was stressed.

In the interaction effect, the number of fruits per plant was affected both by water deficit level and cultivars. Fruit size as well as number of fruits per plant was reduced with reduction in the amount of irrigation water applied for both cultivars. The difference between the cultivars was significant with Melka Shola cultivar consistently having more number of fruits per plant and lower fruit size compared with that of Melkassa Marglobe. The number of smallest fruit size of both tomato cultivars was lower at higher water stress levels. Melka Shola cultivar produced significantly lower smallest fruit size than that of Melkassa Marglobe (Birhanu and Tilahun, 2010).

Irrigation positively influenced tomato productivity. That was due both to the increase in number of berries per plant and the fruit average weight as irrigation increased. The total yield and marketable yields were significantly decreasing as the deficit level was increased. The yield amounted to 45.1 ton ha $^{-1}$ on average for $0 \%$ deficit irrigation treatments and 18.4 ton $\mathrm{ha}^{-1}$ for $75 \%$ deficit irrigation treatment for Melka Shola cultivar. These values were 45.2 ton $\mathrm{ha}^{-1}$ and 13.1 ton $\mathrm{ha}^{-1}$ for Melkassa Marglobe cultivar. The marketable yield was 41.5 ton ha${ }^{1}$ and 15.1 ton $\mathrm{ha}^{-1}$ at $0 \%$ and $75 \%$ deficit levels, respectively for Melka Shola cultivar. These values were, respectively 41.3 ton $\mathrm{ha}^{-1}$ and 11.2 ton $\mathrm{ha}^{-1}$ for Melkassa Marglobe cultivar. The total and marketable yield of tomato was lowest in the most stressed treatment of $75 \%$ deficit level (Birhanu and Tilahun, 2010). For both tomato cultivars, the fresh fruit yields were reduced in $25 \%, 50 \%$, and $75 \%$ deficit level treatments by $6.8 \%, 48.5 \%$, and $71.0 \%$, respectively. Deficit irrigation treatments had pronounced effect on the total soluble solute (TSS) content of the fruits. Fruit soluble solid content increased with increase in water stress. The TSS content of the most stressed treatment ( $75 \%$ deficit level) increased by $2.3 \%$ for Melka Shola and $4.2 \%$ for Melkassa Marglobe relative to the respective fully irrigated treatments $(0 \%$ deficit level)(Birhanu and Tilahun, 2010) 
Performance Evaluation of Introduced Hybrid Tomato (Solanum lycopersicum Mill.) Cultivars in the Rift Valley of Ethiopia

The study was conducted at Melkassa, Debreziet, Koka, Wonji and Ziway districts of Central Rift Valley of Ethiopia during off-season by irrigation since 2015 using 12 known hybrid variety which were believed to be adapted to Ethiopian agro-ecology. Their adaptability and yield performance of 7 newly and 5 previously introduced hybrid tomato varieties was carried out on four locations of major tomato growing areas of Central rift valley of Ethiopia on farmers and researcher fields (Binalfew et al., 2016). The result indicated that, varieties Venis was the highest yielding with preferable quality of tomato in Ethiopia. Awassa, Monica and Tesha varieties are also good yielder tomatoes with extended shelf life with low unmarketable yield. Awassa and Awash River tomato varieties are characterized with large fruits size over the rest newly introduced tomatoes. Galilea has still equivalent fruits size with rational fruit number. The newly introduced cultivar Venise and Tesha were chosen for export due to their reasonable fruit size and low perishable. Tomato cultivars Awassa and Awash River had good acceptance for local fresh consumption (Table 4) (Binalfew et al., 2016).

Table 4.Yield and yield components of hybrid introduced and evaluated tomato varieties.

\begin{tabular}{llllllll}
\hline \multirow{2}{*}{ No } & Cultivar & $\begin{array}{l}\text { No of fruits } \\
\text { per cluster }\end{array}$ & $\begin{array}{l}\text { Yield } \\
\text { (tone/ha) }\end{array}$ & $\begin{array}{l}\text { Fruit number } \\
\text { per plant }\end{array}$ & $\begin{array}{l}\text { unmarketable } \\
\%\end{array}$ & \%TSS & $\begin{array}{l}\text { Average fruit } \\
\text { weight }(\text { gm) }\end{array}$ \\
\hline 1 & Monica & 3.1 & 59.5 & 24.02 & 25.51 & 4 & 102.7 \\
2 & Barnum & 7.3 & 63.7 & 31.68 & 25.08 & 4 & 62.2 \\
3 & Eden & 6.6 & 73.3 & 23.05 & 39.17 & 3.9 & 111.3 \\
4 & Galilea & 6.1 & 57.9 & 20.11 & 39.97 & 3.7 & 126.6 \\
5 & Tesha & 3.6 & $70.3^{* *}$ & 36.17 & 31.02 & 3.1 & 83.2 \\
6 & Bridget 40 & 3.7 & 63.5 & 30.2 & 33.87 & 3 & 95.7 \\
7 & Venise & 3.9 & $87.1^{* *}$ & 40.49 & 22.81 & 3 & 99.5 \\
8 & Awash River & 5.6 & 60.1 & 23.03 & 39.07 & 3.1 & 126.3 \\
9 & Awassa & 6.1 & $69.8^{* *}$ & 25.07 & 12.56 & 3.1 & 126.9 \\
10 & Chibli & 3.8 & 43.4 & 19.27 & 23.25 & 3.9 & 105.9 \\
11 & Momtanz & 3.8 & 54.8 & 18.16 & 30.23 & 3.8 & 108.5 \\
12 & Topspin & 3.6 & 46.8 & 30.06 & 22.52 & 4 & 73.8 \\
\hline LSD & 2.9 & 38.5 & 18 & 20.78 & 1.4 & 61.34 \\
\hline CV & 12 & 22.7 & 15.2 & 16 & 13 & 17 \\
\hline
\end{tabular}

Source: (Binalfew et al., 2016)

In the response of tomato varieties to tested locations, Koka site show the highest of total yield $(93.45$ tone/ha), all most all double of Melkassa area. Tomato varieties show good yield response at Debreziet site next to Koka, 81.76 ton per ha. Concerning number and size of fruits, considerably high number of fruits per plant was observed at Koka, while the larger fruits size recorded at Ziway area. From this, we can clearly understand that the hybrid tomato varieties are more suitable to Debreziet and Koka area which is relatively low temperature and high altitude areas. The low response of tomato at Melkassa might be due to high temperature of the area and low fertility of the soil (Binalfew et al., 2016).

Evaluation of tomato varieties for fruit yield and yield components in western lowland of Tigray, Northern Ethiopia

An experiment was conducted under irrigated condition in 2012 cropping season in Humera agricultural research center (HARC) with Nine nationally released tomato varieties, five of which (Bishola, Chali, Cochoro, Marglobe, Fetan and Melkasalsa) have determinate growth habit while (Metadel, Miya and Melkashola) have semi determinate growth habit with Melkashola as check. Result showed that, there is highly difference for most of the characters among the varieties Days to maturity showed difference. Among the variety studied Miya and Marglobe took the shortest period (96 days) to mature while Bishola was the late (120 days) among the varieties. This finding was an agreement with the finding of Emami et al. (2013) 25 tomato genotypes studied in Iran. Dufera (2013) also reported wide range of difference in maturity for 21 tomato genotypes studied in Mizan Tepi (Chernet and Zibelo, 2014). Number of fruit clusters per plant, total number of fruits per plant, fruit yield per plant single fruit weight, shape index and fruit yield per hectare showed difference among the varieties. The highest marketable yield was obtained by Melkasalsa and the least yield was recorded by Bishola. The association of characters indicated that, fruit yield per plant, number of fruits per plant, number of fruit clusters per plant and shape index are the most important fruit yield components which contributes more to highest fruit yield per hectare. Therefore, to improve fruit yield, selection based on these characters is important (Chernet and Zibelo, 2014).

Summary and conclusions

The climatic and soil conditions of Ethiopia allow cultivation of a wide range of fruit and vegetable crops including 
tomato. In Ethiopia, several tomato varieties had been released nationally for commercial production and small scale farming systems. The average yield of tomato in Ethiopia is low $\left(8\right.$ ton ha $\left.{ }^{-1}\right)$ compared with world average yields of 34 tonha $^{-1}$ (FAOSTAT, 2012). This may be related to limited access and use of improved commercial tomato varieties, adaptation and poor production management. As a result of these, different experiments were conducted in regions and across regions by researchers and higher learning institutions. Under open field and greenhouse condition at JUCAVM, tomato varieties Marglobe and Moneymaker in greenhouse showed the highest total fruit yield per plant. Ten improved tomato varieties with one local check were evaluated at Agaro and Jimma for their yield by JARC. Varieties ARP tomato D2, showed superior and scored a marketable fruit yield of 22.18 ton $\mathrm{ha}^{-1}$ at Jimma. At Agaro, variety Fetan showed highest significance difference in yield 10.67 ton ha ${ }^{-1}$. At Borena YPDARC, there was variation among the varieties evaluated in fruit yield. In Erer valley of Babile, Melka shola scored 30.86 ton $\mathrm{ha}^{-1}$ on and Bishola 28.69 ton ha ${ }^{-1}$. Under irrigation deficit both shoot and fruit weight loss was decreased with increase in stress level while the fruit dry matter weight increased. The total yield and marketable yields were significantly decreasing as the deficit level was increased. Deficit irrigation treatments had pronounced effect on the total soluble solute (TSS) content of the fruits. Fruit soluble solid content increased with increase in water stress. Hybrid evaluation was done at Melkassa, Debreziet, Koka, Wonji and Ziway districts of Central Rift Valley of Ethiopia during off-season under irrigation and the result indicated that varieties Venis was the highest yielding with preferable quality tomato. In the response to tested locations, Koka site show the highest of total yield (93.45 tone $\mathrm{ha}^{-1}$ ), all most all double of Melkassa area. Nine nationally released tomato varieties were evaluated at Humera agricultural research center (HARC). The result showed that there is highly significant difference for most of the characters among the varieties. The highest marketable yield was obtained by Melkasalsa (56.07 ton $\mathrm{ha}^{-1}$ ) and the least yield was recorded by Bishola (17.89 ton ha- ${ }^{-1}$.

\author{
Abbreviations used \\ JARC Jimma Agricultural research center \\ FAO Food and Agricultural Organization \\ CSA Central Statics Authority \\ JUCAM Jimma University College of Agriculture and veterinary Medicine \\ HARC Humera Agricultural research center. \\ YPDARC Yabello Pastoral Development and Agricultural research Center \\ MM Melkassa Marglobe \\ MS Melka Shola \\ TSS total soluble solute
}

\title{
References
}

Adelana, B.O., 1975. Effect of staking on growth and yield of tomatoes, E. Afr. J.,Vol. 41(3): 243-249.

Adelana, B.O., 1978. Effect of flower removal on the tomato. India J. Hortic., Vol. 35(1): 28-34.

Agrisnet, 2010. Tomato. Department of Agriculture, Sikkim, India.

Ambecha, O. Gemechis, Paul, S. and Bezabih, E., 2012. Tomato Production in Ethiopia: Constraints and Opportunities.

Baloch, F.A., 1994. Vegetable crops. In: Horticulture National Book Foundation, Islamabad. 508p.

Benti, G., Degefa, G., Biri, A. and Tadesse, F.,2017. Performance Evaluation of Tomato (Lycopersicon esculentum Mill.) Varieties Under Supplemental Irrigation at Erer Valley, Babile District, Ethiopia. Journal of Plant Sciences, Vol. 5(1):1-5.

Binalfew,T ., Alemu,Y., Geleto,J., Wendimu,G. and Hinsermu,M.,2016. Performance of Introduced Hybrid Tomato (Solanum lycopersicum Mill.) Cultivars in the Rift Valley, Ethiopia. Int. J. of Research in Agriculture and Forestry, Vol.3 (10):25-28.

Birhanu, K. and Tilahun, K., 2010. Fruit yield and quality of drip-irrigated tomato under deficit irrigation. African J. Food, Agr, Nut and Development, Vol.10(2):2139-2151

Chernet, S. and Zibelo, H., 2014. Evaluation of tomato varieties for fruit yield and yield components in western lowland of Tigray, Northern Ethiopia. Int. J. Agric. Res.,Vol. 9, pp.259-264, ISSN 1816-4897 l DOI: 10.39231

Choudhury. B., 1979. Vegetables $6^{\text {th }}$ Revised Edn. The Director, National Book Trust, New Delhi, India, P 46.

CSA , 2012. Report of Federal democratic Republic of Ethiopia, Statistical Report on Socio Economic Characteristics of the Population in Agricultural Households, Land Use, Area and Production of Crops. Addis Ababa, Ethiopia.

CSA, 2015. The Federal Democratic Republic of Ethiopia, Central Statistical Agency, Agricultural Sample Survey, 2015, Volume I, Report on Area and Production of Crops, (Private Peasant Holdings, Meher Season), Addis Ababa, Ethiopia.

Dar, R.A., Sharma, J.P., Nabi, A., and Chopra, S., 2012, Germplasm evaluation for yield and fruit quality traits in 
tomato (Solanum lycopersicon L.). Afr. J. Agric. Res., Vol. 7(46): 6143-6149.

Davis, J.N., and Hobson G.E., 1981, The constituents of tomato fruit the influence of environment, nutrition and genotype. Hort. Sci., Vol. 21(8): 415-421.

Dufera, J.T., 2013. Evaluation of agronomic performance and lycopene variation in Tomato (Lycopersicon esculantum Mill.) genotypes in Mizan, southwestern Ethiopia. World Applied Sciences Journal, Vol.27(11):1450-1454.

Emami, A., M. Homauni-Far, R. Razavi and A.R. Eivazi, 2013. Introduction of superior tomato cultivars (Solanum lycopersicum L.). Pak J. Food Sci. Technol, Vol.1: 19-26.

FAO , 2005. FAOSTAT, Available at http://faostat.fao.org.

FAO, 2006. FAO Production Year Book. Basic Data Unit, Statistics Division, FAO, Rome, Italy, No. 55, pp 125127.

FAO, 2009. Statistical Bulletin, Rome, No. 150, pp 1-2.

FAOSTAT, 2012. Agricultural data. Provisional 2012 Production Indices Data. Crop Primary. (http://apps.fao.org/default.jsp).

FAOSTAT, 2012. Statistical database of the food and agriculture organization of the United Nations.Food and Agriculture Organization (FAO),Rome,Italy. http://faostat.fao.org/.

FAOSTAT,2010. Food and Agriculture Organization of the United Nations.

Gupta, A., Kawatra, A., and Sehgal, S., 2011, Physical-chemical properties and nutritional evaluation of newly developed tomato genotypes. Afr. J. Food Sci. Technol.,Vol. 2(7): 167-172.

Hossain, M.E., Alam, M.J., Hakim, M.A., Amanullah, A.S.M., and Ahsanullah, A.S.M., 2010, An assessment of physicochemical properties of some tomato genotypes and varieties grown at rangpur. Bangladesh Research Publications Journal, Vol. 4(3): 235-243.

Isah, A.S., Amans, E.B., Odion, E.C. and Yusuf, A.A.,2014.Growth Rate and Yield of Two Tomato Varieties (Lycopersicon esculentum Mill) under Green Manure and NPK Fertilizer Rate Samaru Northern Guinea Savanna. International Journal of Agronomy ID 932759, http://dx.doi.org/10.1155/2014/932759.

Jimma Agricultural research center.2014/15.research Progress report .Pp.103-104.

Jimma Agricultural research center.2015/16.research Progress report.Pp:108 -

Lemma, D .2002. Research experience and production prospects. Ethiopian Agricultural Research Organization (EARO), Addis Ababa, Ethiopia, pp. 20-28.

Maerere, A.P., Sibuga, K.P., Mwajombe, K.K., Kovach, J. and Erbaugh, M., 2006. Baseline survey report of tomato production in Mvomero district-Morogoro region, Tanzania. Sokoine University of Agriculture Faculty of Agriculture, Morogoro, pp.1-31.

MARD, 2016. Plant and Animal Quarantine Regulatory, Ethiopian Ministry of Agriculture. Variety Release Booklet.,Addis Ababa, Ethiopia

Meseret,D.R., Ali, M. and Kassahun, B. (2012). Evaluation of tomato (Lycopersicon esculentum Mill.) genotypes for yield and yield components. African Journal of Plant Science and Biotechnology, Vol. 6(Special Issue): 45-49

Mohanty, B.K. and Prusti, A.M., 2006. Evaluation of tomato varieties in black soils of western zone of Orissa. Journal of Tropical Agriculture,Vol. 39(1):55-56.

Olaniyi, J. O., Akanbi, W.B., Adejumo, T. A. and Akande O. G., 2010. Growth, fruit yield and nutritional quality of tomato varieties, Afr. Jour. F. Sc., Vol. 4(6):398 - 402,

Olaniyi,J.O., 2007.Evaluation of Yield and Quality Performance of Grain Amaranth Varieties in the South western Nigeria. Res. J. Agron.,Vol. 1(2): 42-45.

Regassa, D., Tigre, W. and Shiferaw, A., 2016. Tomato (Lycopersicon esculentum Mill.) varieties evaluation in Borana zone, Yabello district, southern Ethiopia. Journal of Plant Breeding and Crop Science, Vol. 8(10):206-210.

Regassa, M.D., Mohammed, A. and Bantte, K., 2012. Evaluation of tomato (Lycopersicon esculentum Mill.) genotypes for yield and yield components. Afr. J. Plant Sci. Biotechnol, Vol. 6(1) : 45-49.

Richardson,K.V.A.,2013.Evaluation of five staked tomato(Lycopersicon esculentum.mill.) Varieties for quality and yield. Gladstone road agricultural center crop research report no. 16

Shah, A.H., Munir, S.U., Amin, N.U., and Shah,S.H., 2011, Evaluation of two nutrient solutions for growing tomatoes in a non-circulating hydroponics system. Sarhad J. Agric.,Vol. 27(4): 557-567.

Shubin, K. S., Dan, E., Maria, R., Valerie, C., Scott, M., Hans, S., Larry, S. and Dennis, N., 2013. Evaluation of Organic Heirloom Tomato Varieties. Midwest Vegetable Trial Report.

Simon J.H., Sobulo, R.A., 1974. Methods for higher tomato yield in Western State of Nigerian. Paper presented at Institute of Agric. research Conference. Ibadan, Nigeria.

Singh N., 2011, Evaluation of Tomato genotypes under net house and open field conditions. M.Sc. thesis, Punjab Agricultural University, Ludhiana, India. 
Tewodros, M. and Asfaw, K., 2013. Promotion and evaluation of improved technologies through participatory approach in South Ethiopia: Experience from hot pepper. Unique Research Journal of Agricultural Sciences, Vol.1(4):057-062.

Wikipedia, 2016. The free encyclopedia, Available at http://en.wikipedia.org, accessed on 8 julay, 2019.

Yeshiwas, Y., Belew, D. and Tolessa, K., 2016. Tomato (Solanum lycopersicum L.) Yield and fruit quality attributes as affected by varieties and growth conditions. World J Agric Sci., 12(6):404-408.

Zhu, W., Zhu, L., Yang, J., Xu, T., Zhu, W.M., Zhu, L.Y., Yang ,Z.J., and Xu, T.W., 2003, Breeding of tomato variety Pohong 909 for multispan plastic greenhouse. Acta Agriculturae Shanghai, Vol.19(3): 33-35. 